\title{
Modelling some physical and mechanical properties of heat-treated Scotch pine using artificial neural network
}

\author{
Sibel Yıldız ${ }^{a}$ * (D), Ayşenur Gürgen ${ }^{a}$ (i)
}

\begin{abstract}
In this study, some physical and mechanical properties of yellow pine wood (Pinus sylvestris), which is used extensively in furniture industry, were tested after heat treatment. The findings obtained were modelled by artificial neural network (ANN) and interval values related to temperature and time variations were tried to be estimated. This study, which makes it easier to reach intermediate values, aims to save the relevant researchers from trial load all of the heating parameters during the furniture design/production stages. In the study scotch pine samples were heat-treated at 150,160, 170, 180, 190 and $200^{\circ} \mathrm{C}$ for 2, 4 and 6 hours, under normal atmosphere conditions. Color changes, weight losses and compression strength parallel to grain values of heat-treated samples were determined. After experimental study, modelling procedure was performed by ANN using two different learning algorithm- Levenberg-Marquardt (LM) and Scaled Conjugate Gradient (SCG) algorithm- 15 different hidden neurons. The best model was obtained from 2-7-6 structure using LM learning algorithm. Mean absolute percentage error (MAPE) of the best model was found below $8.0 \%$ for estimated color parameters. The weight loss and compression strength parallel to grain were $5.79 \%$ and $1.50 \%$, respectively. It was concluded that ANN can be used successfully to predict all studied parameters of heat-treated wood samples.
\end{abstract}

Keywords: Heat-treatment, Modelling, Scotch pine, Artificial Neural Network

\section{Isıl işlem uygulanmış sarıçam odununun bazı fiziksel ve mekanik özelliklerinin yapay sinir ağı kullanılarak modellenmesi}

\begin{abstract}
Özet: $\mathrm{Bu}$ çalışmada, mobilya endüstrisinde yoğun olarak kullanılmakta olan sarıçam odununun (Pinus sylvestris) 1sıl işlem sonrası bazı fiziksel ve mekanik özellikleri test edilmiş, elde edilen bulgular yapay sinir ağı (YSA) ile modellenerek sıcaklık ve süre varyasyonlarına ilişkin ara değerler tahmin edilmeye çalışılmıştır. Ara değerlere ulaşmayı kolaylaştıran bu çalışma, mobilya tasarım/üretim aşamalarında ilgili araştırmacıları, akla gelen tüm 1sıl parametrelerini deneme yükünden kurtarmayı hedeflemektedir. Çalışmada, sarıçam odunu örnekleri, 2, 4 ve 6 saat süreyle $150,160,170,180,190$ ve $200{ }^{\circ} \mathrm{C}$ sıcaklıkta, normal atmosfer ortamında ısıl işleme tabi tutulmuştur. Ardından ısıl işlem uygulanmış örneklerdeki renk değişiklikleri, ağırlık kayıpları ve liflere paralel basınç direnci değerleri belirlenmiştir. Deneysel çalışmanın ardından, yapay sinir ağı ile iki farklı öğrenme algoritmas1 -Levenberg-Marquardt (LM) ve Scaled Conjugate Gradient (SCG) algoritmas1 ve 15 farklı gizli nöron kullanılarak modelleme işlemi gerçekleştirilmiştir. En iyi model LM öğrenme algoritması kullanan 2-7-6 yapısında elde edilmiştir. En iyi modelin ortalama mutlak yüzde hatası (MAPE); tahmin edilen renk parametreleri için \%8,0'in altında bulunmuştur. Ağırlık kaybı ve liflere paralel basınç direnci MAPE değerleri sırasıyla \%5,79 ve \%1,50 olarak bulunmuştur. Sonuç olarak, YSA'nın, ısıl işlem görmüş odun numunelerinin çalışllan bütün parametrelerini tahmin etmede başarıyla kullanılabileceği sonucuna varılmıştır. Anahtar kelimeler: Isıl işlem, Modelleme, Sarıçam, Yapay sinir ağları
\end{abstract}

\section{Introduction}

Wood modification is described as a process that improves the properties of wood (Hill, 2007). In general, wood modification methods can be grouped into physical modification, chemical modification, enzymatic modification, and thermal modification (heat treatment) (Akkılıç et al., 2014). Heat treatment, one of the wood modification methods, is a physical process that results in permanent changes in the chemical composition of the polymer compounds of the wood cell wall. Today, interest in heat-treated wood is increasing due to the decrease in the production of qualified and hard timber, increasing the need for wood used in the building industry, the destruction of forests and government regulations that restrict the use of toxic chemicals (Boonstra and Tjeerdsma, 2006).

The basic object of the heat treatment method is to heat the wood at temperatures above $150{ }^{\circ} \mathrm{C}$ where the chemical reactions accelerated. Since the molecular structure of the wood is modified in the heat treatment application, the performance of the wood also increases. In another words biological resistance against fungi and insects increases with the application of heat treatment (Kamdem et al., 2002; Sivrikaya et al., 2015; Brito et al., 2019). Thanks to the low equilibrium moisture content, less shrinkage and swelling, increased dimensional stability is achieved (Oliveria et al.,

\footnotetext{
$\triangle$ a Karadeniz Technical University, Forest Industry Engineering, Trabzon, Turkey

@ * Corresponding author (İletişim yazarı): sibelyildizz@gmail.com

$\checkmark \quad$ Received (Geliş tarihi): 04.02.2021, Accepted (Kabul tarihi): 14.06.2021
}

Citation (Atıf): Yıldız, S., Gürgen, A., 2021. Modelling some physical and mechanical properties of heat-treated scotch pine using artificial neural network. Turkish Journal of Forestry, 22(2): 135-142. DOI: $\underline{10.18182 / \text { tjf.874681 }}$ 
2010). The thermal insulation capability of wood also increases. Due to the fact that wood is more resistant to outdoor weather conditions, its usage time is also increasing (Yan-Jun et al., 2002). In addition, heat treatment provides decorative color variety (Vinha et al., 2015). However, especially after $200{ }^{\circ} \mathrm{C}$ significant decreases in mechanical properties may occur (Yildiz et al., 2006; Shi et al., 2007).

Artificial neural network (ANN) is an information processing technology inspired by the information processing technique of the human brain (Hassoun, 1995). ANN simulates the way the biological system works. The imitated nerve cells contain neurons, and these neurons connect to each other in various ways to form the network. Artificial nerve cells are similar in structure to biological nerve cells. Artificial neurons connect to each other to form artificial neural networks. Just like biological neurons, artificial neurons have sections where they receive input signals, collect and process these signals, and transmit outputs (Willis et al., 1992). ANN, has been used by researchers working on wood modification methods as well as other disciplines such as medicine (Walczak, 2005; Nasser and Abu-Naser, 2019), engineering science (Adeli, 2001; Moayedi et al., 2020). For example, Tiryaki et al., (2014) developed an ANN model to predict optimum bonding strength of heat treated woods. Zanuncio et al., (2017) reported a study that the predicted of the physical, mechanical and colorimetric properties of Eucalyptus grandis heat-treated wood samples using ANN. Van Nguyen et al., (2018) used ANN for predicting hardness change of wood during heat treatment.

It is very important to determine the optimal conditions of heat treatment that provide the desired properties in wood structure. It is necessary to prevent decreases that may occur especially in mechanical resistance by applying ideal heating programs. This study, intents to save the relevant investigators from trial load all the heating parameters during the furniture design/production stages. For that purpose, some physical and mechanical properties of heattreated Scotch pine wood were investigated and obtained data were modelled with artificial neural networks.

\section{Material and method}

\subsection{Wood material}

In this research, scotch pine (Pinus sylvestris L.) wood which widely used at furniture industry was chosen as raw material. The preparation of the test samples was carried out according to principles of ASTM-D 166687 (1994). The wood samples without any defects were selected and prepared for further experimental studies. The wood samples were cut into $2 \times 2 \times 3 \mathrm{~cm}$ (tangential $\mathrm{x}$ radial $\mathrm{x}$ longitudinal) dimensions and then conditioned $\left(25^{\circ} \mathrm{C}\right.$ and $65 \%$ relative humidity) for further analysis.

\subsection{Heat-treatment}

Heat-treatment was performed in a laboratory oven under the normal atmosphere conditions. The treatment was consisted of a total of 18 variations applied in six different temperatures $\left(150,160,170,180,190\right.$ and $\left.200{ }^{\circ} \mathrm{C}\right)$ and three different time periods (4, 6 and 8 hours). Design of experimental study was given in Table 1 . $\underline{\text { Table 1. Design of experimental study }}$

\begin{tabular}{ccc}
$\begin{array}{c}\text { Heat-treatment } \\
\text { temperature }\left({ }^{\circ} \mathrm{C}\right)\end{array}$ & Heat-treatment duration $(\mathrm{h})$ & Assay no \\
\hline \multirow{2}{*}{150} & 4 & 1 \\
& 6 & 2 \\
& 8 & 3 \\
\hline \multirow{2}{*}{160} & 4 & 4 \\
& 6 & 5 \\
\hline \multirow{2}{*}{170} & 8 & 6 \\
\hline \multirow{2}{*}{180} & 4 & 7 \\
& 6 & 8 \\
& 8 & 9 \\
\hline \multirow{2}{*}{190} & 4 & 10 \\
& 6 & 11 \\
\hline \multirow{2}{*}{200} & 8 & 13 \\
& 4 & 14 \\
& 6 & 15 \\
\hline
\end{tabular}

\subsection{Color measurement}

The color of the outer surface of the heat-treated samples was measured using Konica Minolta CM-2600d spectrophotometer. The color parameters were;

$\mathrm{L}^{*}$ refer to brightness to darkness, $\mathrm{a}^{*}$ refer to intensity in green-red $\left(a^{*}<0\right.$ for green, $a^{*}>0$ for red), $b^{*}$ refer to intensity in blue-yellow ( $b^{*}<0$ for blue, $b^{*}>0$ for yellow).

The color parameters of the heated samples were measured according to the CIELAB color scale (Hunt and Pointer, 2011). Color measurements were performed in the most colorful area of all samples. Four measurements were recorded for each group. The lightness difference $\left(\Delta \mathrm{L}^{*}\right)$, red/green difference $\left(\Delta \mathrm{a}^{*}\right)$ and yellow/blue difference $\left(\Delta \mathrm{b}^{*}\right)$ and total color change $\left(\Delta E^{*}\right)$ were determined according to following Equations 1-4;

$$
\begin{aligned}
& \Delta L^{*}=L_{f}^{*}-L_{i}^{*} \\
& \Delta a^{*}=a_{f}^{*}-a_{i}^{*} \\
& \Delta b^{*}=b_{f}^{*}-b_{i}^{*} \\
& \Delta E^{*}=\sqrt{\Delta L^{2}+\Delta a^{2}+\Delta b^{2}}
\end{aligned}
$$

where; $f$ means final values after heat treatment and $i$ means initial values before heat treatment.

\subsection{Weight loses measurement}

Weight loses of heat-treated samples were determined according to following Equation 5;

Weight loses $(\%)=\frac{W_{i}-W_{f}}{W_{i}} * 100$

where, $W_{i}$ means initial oven dried weight of samples and $W_{f}$ means final oven dried weight of samples.

\subsection{Compression strength parallel to grain measurement}

The compression strength (CS) parallel to grain values for control samples (untreated) and heat-treated samples were determined according to the TS 2595 (1977). 
The compression strength parallel to grain was calculated using the following Equation 6;

$\sigma_{B / /}=\frac{F_{\max }}{a * b}\left(\mathrm{~N} / \mathrm{mm}^{2}\right)$

where: $F_{\max }$ is the force applied on wood specimen $(\mathrm{N})$; $\mathrm{a}$ is the width of the sample (mm); and b is the height of the sample $(\mathrm{mm})$.

\subsection{Artificial neural network}

ANN, one of the artificial intelligence techniques, are information processing software inspired by the human brain. In other words, ANN are computer programs that imitate biological neural networks. Artificial neural networks are self-learning mechanisms that do not require traditional skills. In addition to learning, these networks have the ability to memorize and create relationships between information. Just as biological neural networks have nerve cells, ANNs have artificial nerve cells. The basic structure of an artificial neuron was shown in Figure 1.

An artificial neuron consists of five basic elements: inputs, weights, summation function, activation function and output. Inputs are defined as the informations from the environment or from another neuron. Weights are the elements that show the effect of information on the cell. The summation function is used to calculate the net input by processing all inputs to the cell. The most commonly used summation function is as seen in the Equation 7.

$N e t=\sum_{i=1}^{n} X_{i} * W_{i}$

where $X$ is the input value, $W$ is the weight value of the input and $n$ is the number of inputs. The inputs are multiplied by the weights and the net input is calculated by adding all the values. The input from the summation function is processed in the activation function and the output that the cell will produce for this input is determined.

In ANN, artificial neurons are simply clustered. This clustering is accomplished in layers and then these layers are linked to one another. These layers are classified as input layer, hidden layer and output layer.

The input layer contains neurons that receive inputs from outside. Also, an important point is that the neurons in the input layer do not apply any action on the input values. Only input values in this layer are transmitted to the next layer.

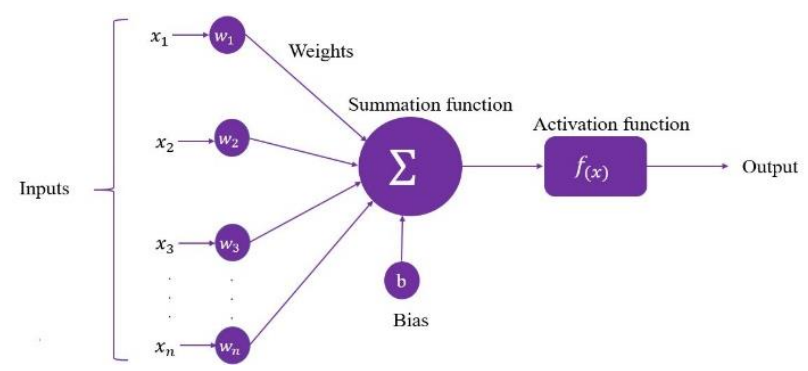

Figure 1. The basic structure of an artificial neuron
The output layer is the layer that contains the neurons that transmit the outputs outside. There may be one or more hidden layer between input layer and output layer. These hidden layers contain a large number of neurons, and these neurons are completely connected with other neurons in the network. Hidden layers contain a large number of neurons, and these neurons are completely connected with other neurons in the network.

One of the important issues in ANN is training the network. In fact, the training of an ANN is the process of determining the optimum weight values in the network. There are some learning algorithms for this purpose. The most well-known learning algorithms are LevenbergMarquardt algorithm, a variation of Newton's method and Conjugate Gradient Algorithm. These two learning algorithms are used successfully in the training of multilayer ANN models.

The main application areas of artificial neural networks can be considered as classification, prediction and modeling.

\subsubsection{Modelling}

Some physical and mechanical properties of heat-treated scotch pine were modeled by using ANN method. $80 \%$ of the data were used for training, $10 \%$ for validation and 10 $\%$ for testing. Two different learning algorithms (Levenberg-Marquardt (LM) and Scaled Conjugate Gradient (SCG) were used in the modeling process. To achieve the best model, all numbers between 1 and 15 were tested as hidden neurons. A total of 30 models were obtained and the best model was selected according to the performance of the models. Heat-treatment duration and heat-treated temperature were used as inputs parameters. The output parameters were $\Delta \mathrm{L}, \Delta \mathrm{a}, \Delta \mathrm{b}, \Delta \mathrm{E}$ values, weight losses and compression strength parallel to grain values of heat-treated samples. The architecture of ANN model was given at Figure 2.

To determine network performance, mean square error (MSE), mean absolute percentage error (MAPE) and correlation coefficient $(\mathrm{R})$ were determined according to following Equations 8-10;

$$
\begin{aligned}
& M S E=\frac{1}{n} \sum_{i=1}^{n}\left(e_{i}-p_{i}\right)^{2} \\
& M A P E=\frac{1}{n} \sum\left|\frac{e_{i}-p_{i}}{e_{i}}\right| * 100 \\
& R=\frac{n \sum_{i=1}^{n} e_{i} p_{i}-\left(\sum_{i=1}^{n} e_{i}\right)\left(\sum_{i=1}^{n} p_{i}\right)}{\sqrt{n \sum_{i=1}^{n} p_{i}{ }^{2}-\left(\sum_{i=1}^{n} p_{i}\right)^{2}} \sqrt{n \sum_{i=1}^{n} p_{i}{ }^{2}-\left(\sum_{i=1}^{n} p_{i}\right)^{2}}}
\end{aligned}
$$

where, $e$ is the experimental result, $p$ is the prediction result, $p_{m}$ is the mean of the prediction results and $n$ is the number of samples.

\section{Results and discusion}

$\Delta \mathrm{L}^{*}, \Delta \mathrm{a}^{*}, \Delta \mathrm{b}^{*}, \Delta \mathrm{E}^{*}$ changes, weight losses and CS values of heat-treated samples were given at Figure 3-8, respectively.

$\Delta \mathrm{L}^{*}$ refers to the lightness-darkness of the color parameters. The differences in colors and their locations are determined according to the $\mathrm{L}^{*}, \mathrm{a}^{*}$ and $\mathrm{b}^{*}$ color coordinates in the CIEL*a*b* color scheme. In this scheme, $\mathrm{L}^{*}$ 
(lightness) is located on the black-white axis $\left(\mathrm{L}^{*}=0\right.$ for black, $L^{*}=100$ for white), $a^{*}$ on the red-green axis (positive values for red and negative values for green), and $b^{*}$ for the yellow-blue axis (positive values for yellow and negative values for blue) (McGuire, 1992; Oliver et al., 1992; Budakçı et al., 2012). As can be seen in Figure 3, as the heat treatment time and the temperature increase the $\Delta \mathrm{L}^{*}$ value of the wood increased continuously in the negative direction. According to this, it is possible to say that the color of the wood has become darker. Color is an aesthetic issue. The color of the wood becomes darker as a result of the oxidative and hydrolytic (hydrolysis-related) reactions that occur during the heat treatment application (Korkut and Kocaefe, 2009). Color changes are a positive effect especially on coniferous trees. Color can add a more preferable feature to heat treated coniferous trees than those without heat treatment, therefore darkening of color can give them a new market potential (Johansson, 2005). The color change that occurs in the wood depends on the treatment method. The darkening of the color of the wood occurs in the samples treated in oxygen atmosphere rather than the nitrogen atmosphere (Aydemir and Gündüz, 2009).

The increment of $\Delta \mathrm{a}^{*}$ value denotes the red intensity and decline of $\Delta \mathrm{a}^{*}$ denotes the green intensity. When Figure
4 was examined, it was seen that the increase in heat treatment temperature and duration increased the red color intensity of the wood.

The increment of $\Delta b^{*}$ value denotes the intensity of the color yellow decline of $\Delta \mathrm{b}^{*}$ indicates the intensity of the blue color. When Figure 5 was examined, it was shown that the different heat treatment temperatures and durations affect the wood samples in different rates. Especially in the heat treatment applied at $200{ }^{\circ} \mathrm{C}$ for 8 hours, it was seen that the increase in blue color intensity.

$\Delta \mathrm{E}^{*}$ denotes the color changes. As can be seen from the Figure 6, the color change increased with the increasing of heat treatment time and temperature. Color has the potential to determine the quality of heat treatment application. The chemical reasons of the color changes in wood during the heat treatment application are not fully defined in the literature (Korkut and Kocaefe, 2009). However, in studies conducted on this subject, it has been shown that the main causes of color changes are degradation of hemicellosis, lignin and some extractive substances. In the heat treatment application, as the temperature and time increases, the color darkness of the wood increases (Nuopponen, 2005).

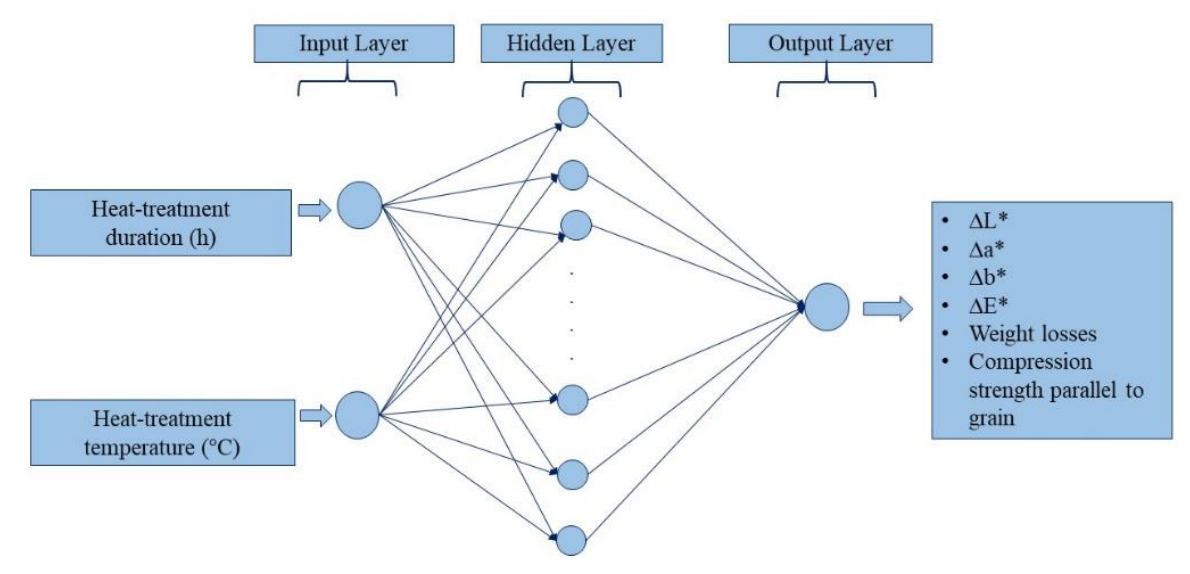

Figure 2. Architecture of ANN model

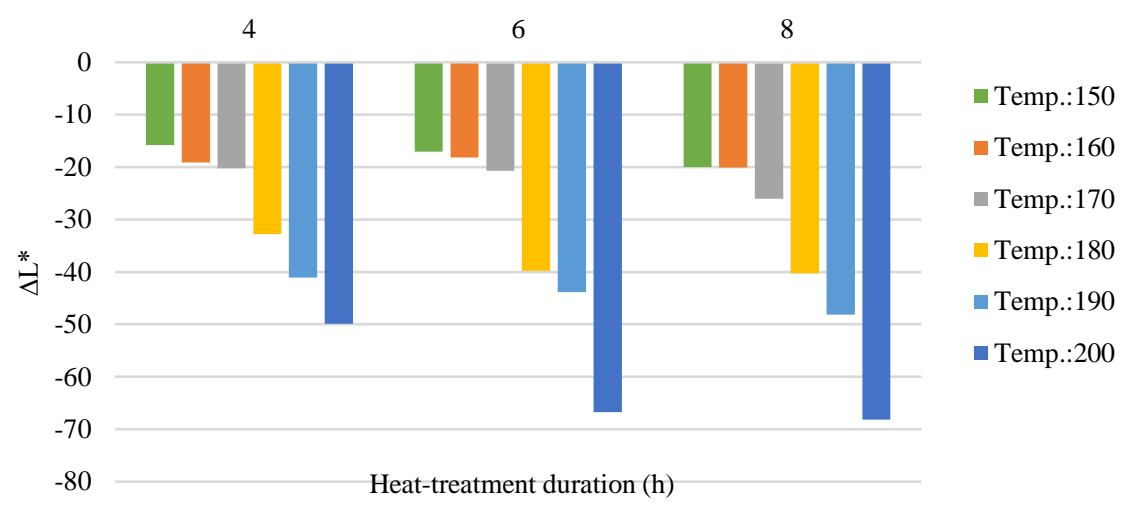

Figure 3. $\Delta \mathrm{L}^{*}$ changes of heat-treated wood samples 


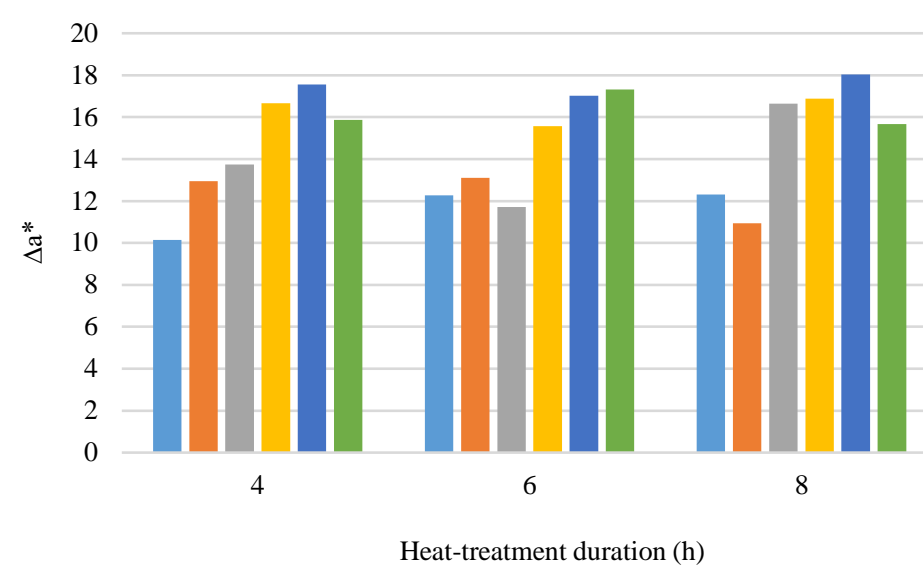

Figure $4 . \Delta \mathrm{a}^{*}$ changes of heat-treated wood samples

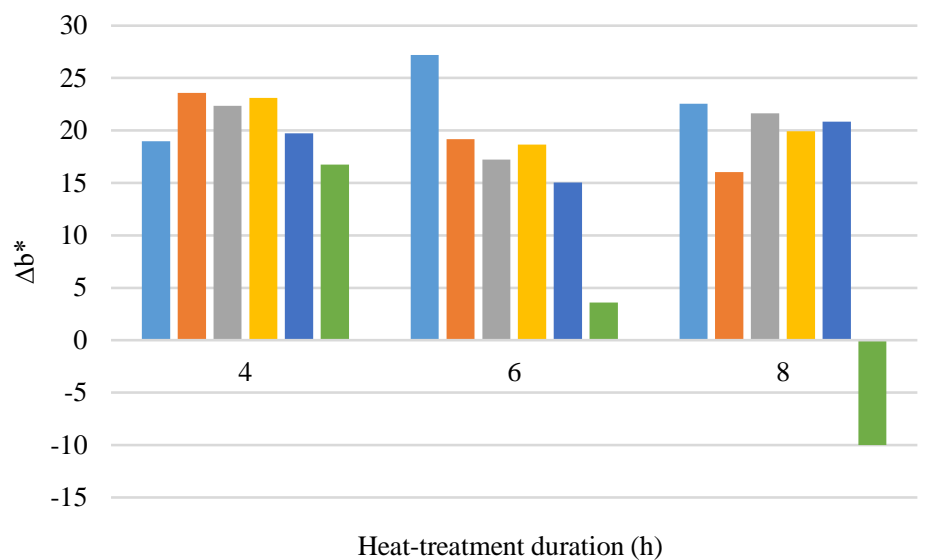

- Temp.:150

- Temp.:160

- Temp.:170

- Temp.:180

- Temp.:190

- Temp.:200

Figure 5. $\Delta \mathrm{b}$ changes of heat-treated wood samples

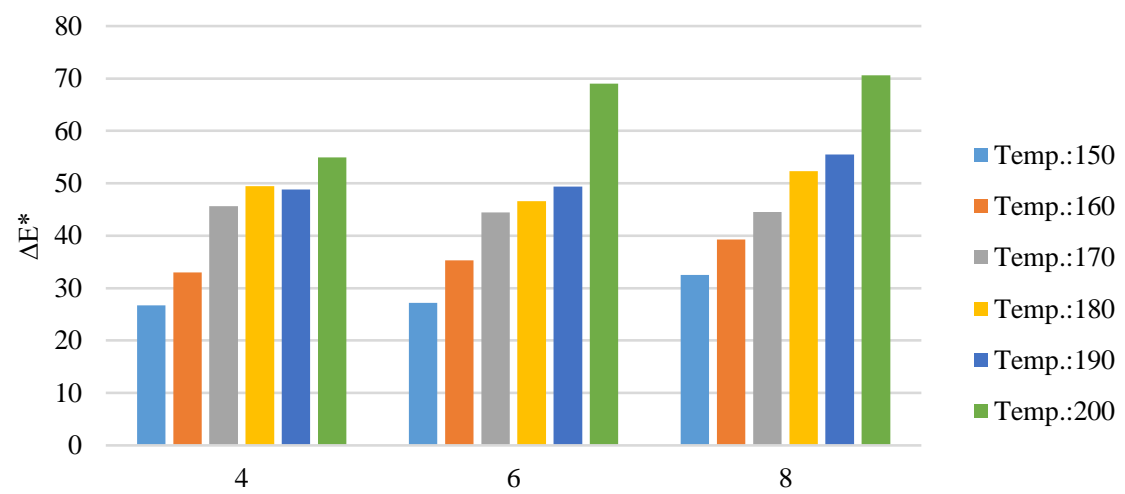

Heat-treatment duration (h)

Figure 6. $\Delta \mathrm{E}$ changes of heat-treated wood samples 
When Figure 7 was examined, it was seen that as the heat treatment time and temperature increased, the weight loss increased in wood. It is thought that weight loss is caused by the loss of water in the wood structure due to the decrease in the existing hydroxyl groups, material losses in the cell wall and the degradation of hemicelluloses (Fengel and Wegener, 1989; Viitanen et al., 1994). In low temperature heat treatment causes low mass loss with the loss of volatile and bound water. The loss of macromolecular compounds occurs above $100{ }^{\circ} \mathrm{C}$ and the advancing time and temperatures increase the mass loss. If the process is not optimal, there will be more change in the structure of the wood (Millett, 1972).

When Figure 8 was examined, it was seen that the compression strength parallel to grain values decreases especially at $200{ }^{\circ} \mathrm{C}$ temperature. It has been reported that while biological resistance and stability increase during heat treatment, significant decreases in mechanical properties may occur, especially after temperatures of $200^{\circ} \mathrm{C}$.

In a previous study, some mechanical and physical properties of beech (Fagus orientalis) wood samples heated at temperatures $170,180,190$, and $212{ }^{\circ} \mathrm{C}$ for $2 \mathrm{~h}$ with Thermo-Wood method were investigated. The results were compared with the oven-dried reference samples. It has been reported that depending on the increase of heat treatment temperature, the bending strength was decreasing, the compression strength parallel to the grain and modulus of elasticity values of samples increased (Kol et al., 2017). In a previous study, it was determined that the compression strength of the eucalyptus wood decreased significantly depending on the heat treatment temperature and time. The compression strength value of the samples that were heat treated at $180{ }^{\circ} \mathrm{C}$ for 10 hours was $19 \%$ lower than that of the control samples (Unsal and Ayrilmis, 2005).

After the experimental study, the modelling procedure was carried out using different learning algorithms and hidden neuron number. Then, the best model was obtained in 2-7-6 structure using the LM learning algorithm. Performance values of the best model were shown in Figure 9. Comparison of real values and ANN results of studied parameters were given in Table 2.

MSE value represents the difference between the obtained data and the estimated value of the model, and if the values of the data in different tests are not close to each other, it is not meaningful to compare the MSE values. In this study, since the compression strength values were much higher than the other data, the MSE values seem high, but this does not indicate that the model is unsuccessful.

MAPE value refers to the error rate of the prediction capability of the model. In this study, the lowest MAPE value is seen in compression strength values with $1.5 \%$ and $\Delta \mathrm{b}$ values with $8.3 \%$. It can be concluded that the obtained ANN model predicts all values with high accuracy since the MAPE values of all the studied values are below $10 \%$.

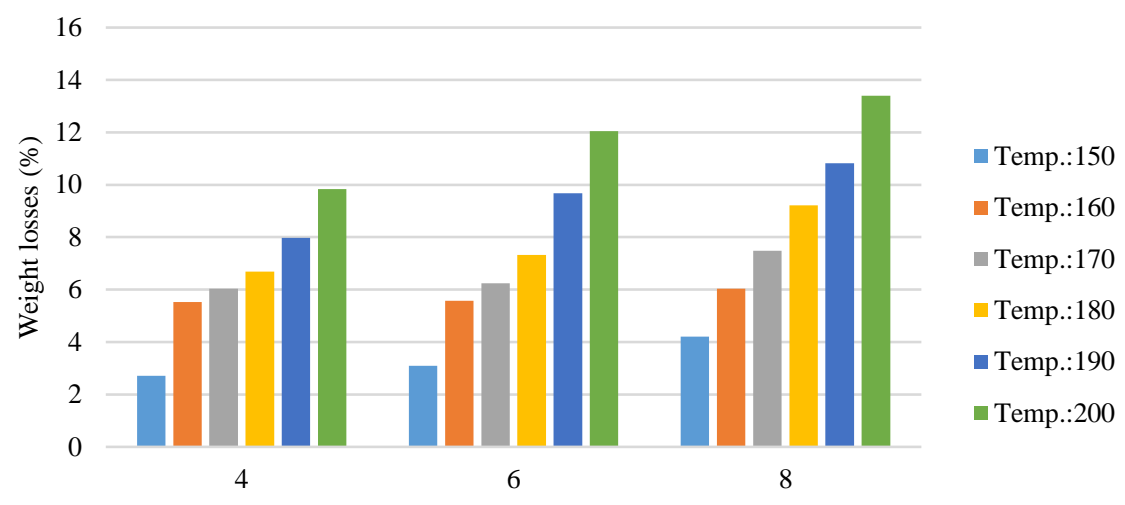

Heat-treatment duration (h)

Figure 7. Weight losses of heat-treated wood samples

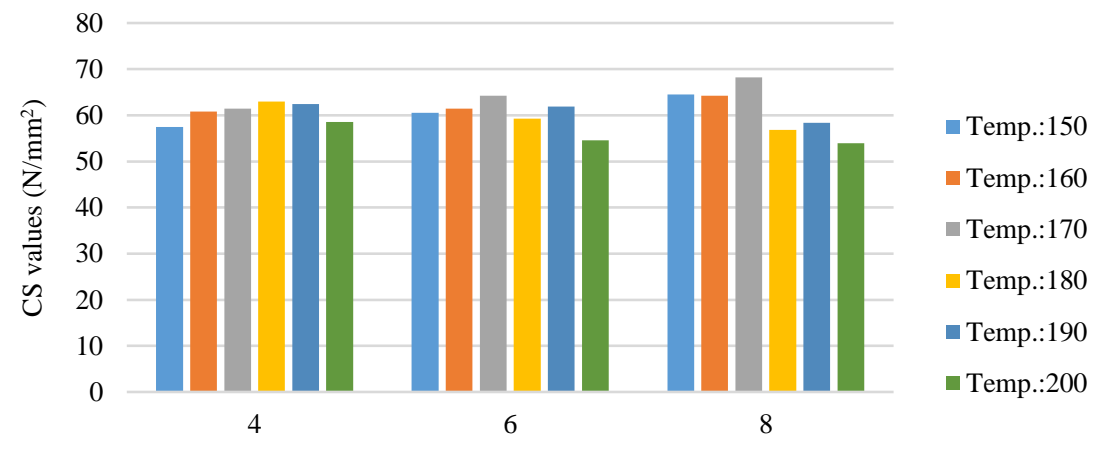

Heat-treatment duration $(\mathrm{h})$

Figure 8. Compression strength parallel to grain (CS) values of heat-treated wood samples 


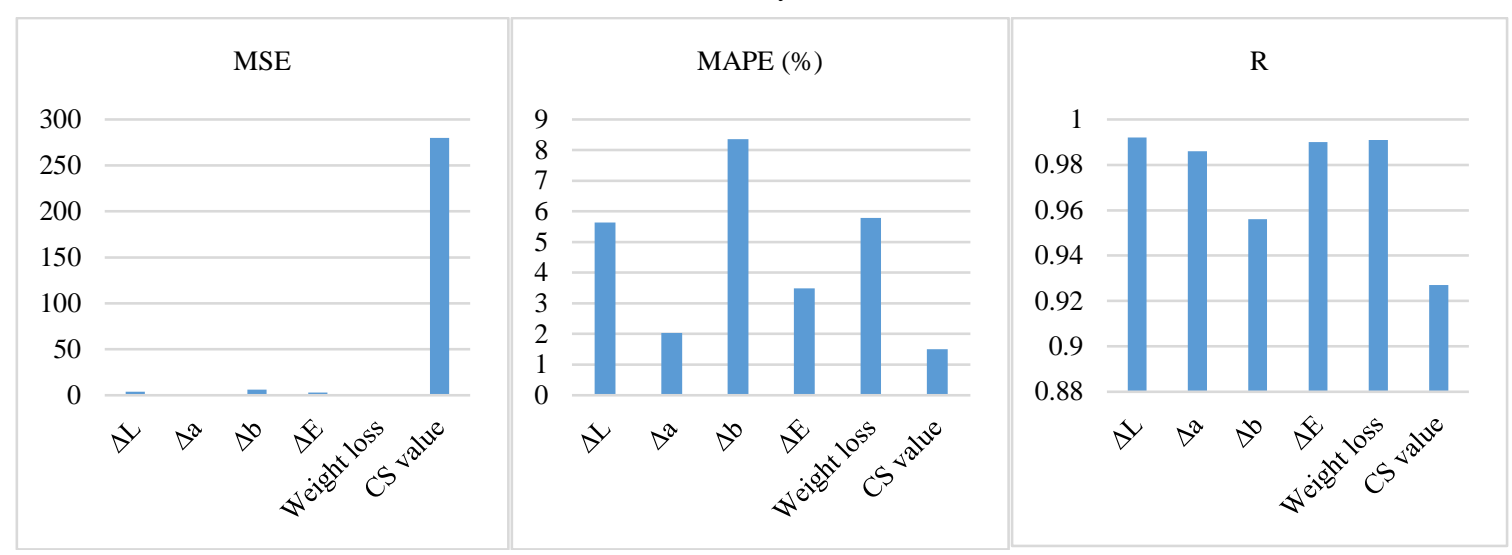

Figure 9. Performance values of the best ANN model

Table 2. Comparison of real values and ANN results of studied parameters

\begin{tabular}{|c|c|c|c|c|c|c|c|c|c|c|c|c|}
\hline \multirow[b]{2}{*}{$\begin{array}{c}\text { Assay } \\
\text { no }\end{array}$} & \multicolumn{2}{|c|}{$\Delta \mathrm{L}$} & \multicolumn{2}{|c|}{$\Delta \mathrm{a}$} & \multicolumn{2}{|c|}{$\Delta \mathrm{b}$} & \multicolumn{2}{|c|}{$\Delta \mathrm{E}$} & \multicolumn{2}{|c|}{ Weight losses (\%) } & \multicolumn{2}{|c|}{ CS values $\left(\mathrm{N} / \mathrm{mm}^{2}\right)$} \\
\hline & $\begin{array}{c}\text { Real } \\
\text { values }\end{array}$ & $\begin{array}{c}\text { ANN } \\
\text { results }\end{array}$ & $\begin{array}{c}\text { Real } \\
\text { values }\end{array}$ & $\begin{array}{c}\text { ANN } \\
\text { results }\end{array}$ & $\begin{array}{c}\text { Real } \\
\text { values }\end{array}$ & $\begin{array}{c}\text { ANN } \\
\text { results }\end{array}$ & $\begin{array}{c}\text { Real } \\
\text { values }\end{array}$ & $\begin{array}{c}\text { ANN } \\
\text { results }\end{array}$ & $\begin{array}{c}\text { Real } \\
\text { values }\end{array}$ & $\begin{array}{c}\text { ANN } \\
\text { results }\end{array}$ & $\begin{array}{c}\text { Real } \\
\text { values }\end{array}$ & $\begin{array}{c}\text { ANN } \\
\text { results }\end{array}$ \\
\hline 1 & -15.79 & -17.73 & 10.14 & 11.59 & 18.97 & 26.01 & 26.68 & 23.15 & 2.71 & 3.27 & 57,46 & 55,16 \\
\hline 2 & -17.07 & -14.77 & 12.26 & 12.31 & 27.20 & 25.75 & 27.17 & 26.69 & 3.10 & 3.35 & 60,49 & 60,39 \\
\hline 3 & -20.00 & -20.60 & 12.30 & 12.36 & 22.55 & 21.99 & 32.55 & 33.17 & 4.21 & 4.04 & 64,50 & 64,66 \\
\hline 4 & -19.11 & -19.73 & 12.95 & 12.77 & 23.58 & 24.27 & 33.00 & 33.69 & 4.96 & 4.51 & 56,96 & 58,58 \\
\hline 5 & -18.15 & -19.84 & 13.11 & 12.72 & 19.19 & 22.32 & 35.32 & 37.53 & 5.54 & 5.08 & 60,85 & 60,48 \\
\hline 6 & -20.07 & -18.57 & 10.94 & 11.02 & 16.03 & 16.34 & 39.25 & 40.38 & 5.58 & 5.87 & 68,03 & 67,95 \\
\hline 7 & -20.24 & -21.79 & 13.75 & 13.92 & 22.34 & 22.42 & 45.65 & 44.10 & 6.04 & 5.77 & 61,49 & 62,00 \\
\hline 8 & -20.69 & -21.33 & 11.71 & 11.74 & 17.21 & 15.72 & 44.45 & 42.22 & 6.25 & 6.44 & 64,21 & 64,29 \\
\hline 9 & -26.02 & -27.47 & 16.65 & 16.43 & 21.64 & 22.24 & 44.51 & 42.65 & 7.50 & 7.26 & 68,25 & 68,15 \\
\hline 10 & -32.80 & -31.30 & 16.67 & 16.70 & 23.09 & 22.54 & 49.44 & 49.91 & 6.69 & 7.11 & 62,95 & 62,62 \\
\hline 11 & -39.77 & -37.37 & 15.57 & 15.83 & 18.67 & 17.19 & 46.61 & 43.69 & 7.32 & 7.93 & 59,24 & 62,60 \\
\hline 12 & -40.26 & -42.85 & 16.88 & 17.31 & 19.91 & 20.75 & 52.31 & 51.58 & 9.21 & 9.70 & 56,83 & 57,32 \\
\hline 13 & -41.06 & -40.93 & 17.56 & 17.74 & 19.72 & 19.21 & 48.82 & 49.03 & 7.99 & 8.36 & 62,47 & 62,74 \\
\hline 14 & -43.82 & -43.48 & 17.02 & 16.89 & 15.04 & 16.35 & 49.36 & 51.18 & 9.69 & 9.11 & 61,88 & 61,72 \\
\hline 15 & -48.17 & -45.01 & 18.04 & 17.75 & 20.84 & 19.12 & 55.50 & 57.06 & 10.83 & 10.47 & 58,34 & 57,99 \\
\hline 16 & -49.85 & -44.60 & 15.86 & 16.55 & 16.75 & 10.47 & 54.93 & 53.92 & 9.84 & 9.44 & 58,51 & 64,01 \\
\hline 17 & -66.71 & -67.32 & 17.32 & 17.19 & 3.61 & 3.60 & 69.02 & 66.85 & 12.05 & 12.12 & 52,56 & 52,47 \\
\hline 18 & -68.15 & -67.95 & 15.66 & 15.73 & -10.02 & -9.97 & 70.64 & 71.63 & 13.40 & 13.39 & 53,93 & 53,99 \\
\hline
\end{tabular}

$\mathrm{R}$ value expresses the closeness of the obtained value and the prediction value, and it can be said that the closer it is to 1.0, the closer the predicted values of that model to the data obtained. All $\mathrm{R}$ values in this study were higher than 0.9 and it can be concluded that the prediction performance of the selected model is high.

Comparison of real values and ANN results of studied parameters were given in Table 2. It was seen that ANN results and real values were very close to each other and it has been concluded that ANN models can be successfully used to estimate the color change, weight losses and CS values of pine wood samples. In a previous study, it was aimed to predict the color change of heat-treated wood during artificial weathering by ANN model. The network included an input layer consisting of three input nodes, namely, the weathering exposure time, heat treatment temperature, and heat-treated wood species, a hidden layer using six neurons and an output layer consisting of one output node, namely heat-treated wood color. According to the results, MAPE values were $8.17,9.70$, and $9.85 \%$ for the prediction of color change $(\Delta \mathrm{E})$ for training, validation and testing data sets, respectively. $R$ value were above 0.92 of the proposed ANN model for all data sets. These results showed that the ANN model can be successfully used for predicting the color change of heat-treated wood (Nguyen et al., 2019).

\section{Conclusion}

In this study some physical and mechanical properties of heat-treated scotch pine wood were investigated and modelled with artificial neural networks. It was concluded that, as the heat treatment time and the temperature increase the $\Delta \mathrm{L}$ value of the wood increased continuously in the negative direction. The color of the wood has become darker. Weight loss has increased in the variations of heat treatment applied at higher temperatures and longer times. The compression strength parallel to grain values decreased especially in the variation heated at $200{ }^{\circ} \mathrm{C}$ temperature for 8 hours. When the model performance was examined, it was concluded that ANN applications can be easily applied in such studies. It was seen the obtained data and the estimated values of the model were close to each other. The best model was obtained from 2-7-6 structure using LM learning algorithm. Since the MAPE values of all the studied values are below $10 \%$, it can be concluded that the obtained model predicts all values with high accuracy. All $\mathrm{R}$ values in this study were higher than 0.9 and it can be concluded that the prediction performance of the selected model was high. At the end of the study, it was concluded that modeling experimental data with ANN modeling provides chemical, time and labor savings. Thanks to the proposed ANN model, it was possible to predict with high accuracy the color changes, weight loss and pressure resistance values parallel 
to the fibers of non-worked heat treatment temperatures and times (for example, $175{ }^{\circ} \mathrm{C} \quad 2.5 \mathrm{~h}$ heat treatment application). It was suggested that ANN applications should be made widespread in similar studies.

\section{Acknowledgments}

This study was presented as oral presentation at VI. International Furniture Congress- IFC2020 (02-05 November 2020) in Trabzon, Turkey.

\section{References}

Adeli, H., 2001. Neural networks in civil engineering: 1989-2000. Computer-Aided Civil and Infrastructure Engineering, 16(2): 126-142.

Akkılıç, H., Kaymakcı, A., Ünsal, Ö., 2014. Isıl işlem uygulanmış ahşap malzemenin dış cephe kaplaması olarak değerlendirilme potansiyeli, 7. Ulusal Çatı \& Cephe Sempozyumu, 3-4 Nisan, İstanbul s. 1-9.

ASTM-D-1666-87, 1994. Standard Test Methods for Conducting Machining Tests of Wood and Wood-Base Materials. Annual Book of ASTM Standards, Philadelphia, USA.

Aydemir, D., Gündüz, G., 2009. The effect of heat treatment on physical, chemical, mechanical and biological properties of wood. Journal of Bartın Faculty of Forestry, 11(15): 71-81.

Boonstra, M.J., Tjeerdsma, B., 2006. Chemical analysis of heat treated softwoods. Holz als Roh-und Werkstoff, 64(3): 204211.

Brito, J.O., Dias Júnior, A.F., Lana, A.Q., Andrade, C.R., Bernardes, F.F., 2019. Biological resistance of heat-treated wood of Pinus caribaea and eucalyptus saligna. Maderas. Ciencia y tecnología, 21(2): 223-230.

Budakçı, M., Sönmez A., Pelit H., 2012. The color changing effect of the moisture content of wood materials on water borne varnishes. BioResources, 7(4): 5448-5459.

Fengel, D., Wegener, G., 1989. Wood: Chemistry, Ultrastructure, Reactions. Walter De, Germany.

Hassoun, M.H., 1995. Fundamentals of Artificial Neural Networks. MIT Press, London, England.

Hill C.A., 2007. Wood Modification: Chemical, Thermal and Other Processes. John Wiley \& Sons, England.

Hunt, R.W.G., Pointer M.R., 2011. Measuring Colour. John Wiley \& Sons, USA.

Johansson, D., 2005. Strength and colour response of solid wood to heat treatment. Licentiate Thesis, Department of Skellefteå Campus, Luleå Tekniska Universitet, Skellefteå-Sweden.

Kamdem, D., Pizzi, A., Jermannaud, A., 2002. Durability of HeatTreated Wood. Holz als Roh-und Werkstoff, 60(1): 1-6.

Kol, H.Ş., Keskin, S.A., Vaydoğan, K.G., 2017. Effect of heat treatment on the mechanical properties and dimensional stability of beech wood. Journal of Advanced Technology Sciences, 6(3): 820-830.

Korkut, S., Kocaefe D., 2009. Effect of heat treatment on wood properties. Duzce University Journal of Forestry, 5(2): 11-34.

McGuire, R.G., 1992. Reporting of objective color measurements. HortScience, 27(12): 1254-1255.

Millett, M., 1972. Accelerated aging: Residual weight and flexural properties of wood heated in air at $115^{\circ} \mathrm{C}$ to $175^{\circ} \mathrm{C}$. Journal of Wood Science, 4: 193-201.

Moayedi, H., Mosallanezhad, M., Rashid, A.S.A., Jusoh, W.A.W., Muazu, M.A., 2020. A systematic review and meta-analysis of artificial neural network application in geotechnical engineering: Theory and applications. Neural Computing and Applications, 32(2): 495-518.

Nasser, I.M., Abu-Naser, S.S., 2019. Predicting tumor category using artificial neural networks. International Journal of Academic Health and Medical Research, 3(2): 1-7.
Nguyen, T.T., Van Nguyen, T.H., Ji, X., Yuan, B., Trinh, H.M., Do, K.T.L. Guo, M., 2019. Prediction of the color change of heat-treated wood during artificial weathering by artificial neural network. European Journal of Wood and Wood Products, 77(6): 1107-111

Nuopponen, M., 2005. Thermal modification of wood and FT-IR and UV Raman spectroscopic; Studies of its extractable compounds. Ph.D. Thesis, Helsinki University, HelsinkiSweden.

Oliveira, R.M.D., Brisolari, A., Sales A., Gonçalves D., 2010. Wettability, Shrinkage and color changes of Araucaria angustifolia after heating treatment. Materials Research, 13(3): 351-354.

Oliver, J., Blakeney, A., Allen H., 1992. Measurement of flour color in color space parameters. Cereal Chemistry, 69(5): 546551.

Sivrikaya, H., Can, A., de Troya T., Conde, M., 2015. Comparative biological resistance of differently thermal modified wood species against decay fungi, Reticulitermes grassei and Hylotrupes bajulus Maderas. Ciencia y Tecnología, 17(3): 559570.

Shi, J.L., Kocaefe, D., Zhang, J., 2007. Mechanical behaviour of quebec wood species heat-treated using thermowood process. Holz als Roh-und Werkstoff, 65(4): 255-259.

Tiryaki, S., Özşahin, Ş., Yıldırım, İ., 2014. Comparison of artificial neural network and multiple linear regression models to predict optimum bonding strength of heat treated woods. International Journal of Adhesion and Adhesives, 55: 29-36.

TS-2595, 1977. Wood-Determination of Ultimate Stress in Compression Parallel to Grain. Turkish Standards Institution, Turkey.

Unsal, O., Ayrilmis N., 2005. Variations in compression strength and surface roughness of heat-treated turkish river red gum (Eucalyptus camaldulensis) wood. Journal of Wood Science, 51(4): 405-409.

Van Nguyen, T. H., Nguyen, T.T., Ji, X., Do, K.T.L., Guo, M., 2018. Using artificial neural networks (ANN) for modeling predicting hardness change of wood during Heat Treatment. IOP Conference Series: Materials Science and Engineering, 394(3): 1-7.

Viitanen, H., Jämsä, S., Paajanen, L., Nurmi A., Viitaniemi P., 1994. The effect of heat treatment on the properties of spruce. A preliminary Report. The International Research Group on Wood Preservation, 29 May-3 June, Nusa Dua, Bali, Indonesia, pp. 1-4.

Vinha, A.J., Carvalho, A.G., Teixeira de Souza, M., Marangon Jardim, C., de Cassia Oliveira Carneiro, A., Luiz Colodette, J., 2015. Effect of extractives on wood color of heat treated Pinus radiata and Eucalyptus pellita. Maderas. Ciencia y Tecnología, 17(4): 857-864.

Walczak, S. 2005. Artificial neural network medical decision support tool: Predicting transfusion requirements of ER patients. IEEE Transactions on Information Technology in Biomedicine, 9(3): 468-474.

Willis, M.J., Montague, G.A., Di Massimo, C., Tham, M.T., Morris A.J., 1992. Artificial neural networks in process estimation and control. Automatica, 28(6): 1181-1187.

Yan-Jun, X., Yi-Xing, L., Yao-Xing S., 2002. heat-treated wood and its development in Europe. Journal of Forestry Research, 13(3): 224-230.

Yildiz, S., Gezer, E.D., Yildiz U.C., 2006. Mechanical and chemical behavior of spruce wood modified by heat. Building and Environment, 41(12): 1762-1766.

Zanuncio, A.J.V., Carvalho, A.G., Da Silva, L.F., Da Silva, M.G., Carneiro, A.D.C.O., Colodette, J.L., 2017. Prediction of the physical, mechanical and colorimetric properties of Eucalyptus grandis heat-treated wood using artificial neural networks. Scientia Forestalis/Forest Sciences, 45(113): 109-118. 